\title{
My Friend Ricardo Ferreira, an Impressive Natural Philosopher
}

\author{
Constantino Tsallis* \\ Centro Brasileiro de Pesquisas Físicas, Rua Dr. Xavier Sigaud 150, 22290-180 Rio de Janeiro, RJ, Brazil
}

I have met, during my life, only two people to whom I would immediately and heartily reserve the title of natural philosopher - a title which in my personal conception designates the supreme form of science, the one that was practiced by Aristotle. They are Murray Gell-Mann, the Nobel laureate in Physics, and Ricardo Ferreira. These brief lines are dedicated to the celebration of the 80th birthday anniversary of the latter.

I first met him, as far as I remember, around 1980, at the Centro Brasileiro de Pesquisas Físicas (CBPF). He was joining the Department of Theoretical Physics that I was heading. Immediately after, I resigned as Head: I was less than 40 years old, and I felt very embarrased to have as an administrative subordinate a scientist of the stature of Ricardo. We immediately did new elections, and he became the Head of the department. Sometime after, there was a minor conflict with somebody who (irresponsibly) accused him of having neglected on purpose some administrative demand. Such a suspicion was unacceptable by Ricardo, and he resigned on the spot. He referred, while resigning, to his father Antonio Ferreira, and behaved like he always did, with courage. Frequently, the manner through which a man deals with adversity gives the measure of his character. Konrad Lorenz, the Nobel laureate in Medicine, wrote in a couple of places that there are some events that, in some animal species, cause imprint. For me, in some sense, that was it. Ricardo's scientific curriculum, the essential honesty and generosity of his personality, his reference to his father, and his courage, was good enough for me: from that point on, it became clear in my mind that I wanted to become his friend, as if he was a sort of (second) older brother for me. And, indeed, slowly, we started becoming friends - Saint-Exupery brilliantly describes such things in his amazing Le Petit Prince.

Some years later, another institutional crisis occurred, involving myself this time. I was once again Head - of the Department of Condensed Matter Physics, that had been created. That was the first time I was in charge of an unit which had both experimental and theoretical constituents -

*e-mail: tsallis@cbpf.br
Ricardo was one of the members. That was a new and enriching experience for me. But not without nontrivial difficulties, of course. Regretfully, an authority conflict emerged with one of the members. Ricardo, although in cordial terms with my opponent, stood on my side. One day, while we were getting out from the elevator, he told me "Voce nao agrediu, voce revidou. Porque no sertao do Nordeste, e nos vales secos da Grecia, nao se leva desaforo para casa." Once again, I felt very deep empathy for that man.

I will finish my paint spots of Ricardo's fascinating personality by recalling a short dialog that I had with him, at the hotel, during one of the huge Brazilian annual meetings on Condensed Matter Physics. I had just learnt that some wealthy gentleman from USA made a generous donation to the College where he had received, many decades ago, Chemistry lessons from Ricardo, and that he wanted this to constitute an annual award to be named "Ferreira Scholarship". I was very impressed by the fact that a very rich man was still remembering, some thirty years later and in such a strong and touching manner, that foreign professor that was teaching in a neat Brazilianaccent English. So, I said to Ricardo "This is incredible, such a thing only happens to you! How were you teaching those young people?" Ricardo's answer: "I do not know. I just taught to them until a certain point, and then let them free." Freedom, wisdom and simplicity: that is a good part of the greatness of Ricardo Ferreira.

Let me now dedicate a few words to our scientific collaboration on biogenesis. ${ }^{2-4}$ One day, he gave to me an article by the Nobel laureate Phil Anderson ${ }^{5}$ and suggested me to read it: "I think you will like it", he said. Indeed, I liked it. I read it on a sunny Saturday, at the side of a swimming pool of the Club Caiçaras, in Rio de Janeiro. The possible emergence of the first prebiotic forms - on Earth and/or elsewhere - was there approached in terms of complementarity. That idea fascinated me, and it came to my mind that perhaps the appearance of codified self-replicating polymers happened through a critical phenomenon. I wrote then a simple renormalization group equation on a Coca Cola napkin, and saw that it 
had a critical fixed point (i.e., unstable under iteration), in addition to the two expected trivial ones (i.e., stable). The equation was

$$
K^{\prime}+4 K^{\prime 2}=K+3 K^{2}+8 K^{3}
$$

where $K$ stands for the fugacity of a complementary pair, say adenine-thymine or cytosine-guanine or whatever similar. I immediately verified the existence of the trivial fixed points $K=0$ (no growth) and $K \rightarrow \infty$ (infinite growth). But I also verified the existence of a nontrivial unstable fixed point, namely $K=1 / 8$, corresponding to finite growth! This kind of fixed point confirmed the possibility of a phase transition. I was very excited, and, back to my house, I called by phone Ricardo to tell him what appeared to me as very interesting. He immediately understood what was going on - surely better than myself, who never had any serious knowledge at all about biogenesis -, and became very excited as well. He told me "You show me this on Monday at CBPF." It then started a long and fascinating collaboration with Ricardo. We published a short note with only one kind of complementary pair. We then decided to generalize the approach, introducing in the renormalization group two possibly different fugacities, namely $K_{A T}$ and $K_{C G}$. This hypothesis was closer to reality, and brought into the theory several interesting new aspects, such as diversity and selection. I was learning a lot with Ricardo. Every new mathematical possibility immediately raised in Ricardo's mind lots of questions concerning its interpretation in terms of physical, chemical and biological plausibility. He shared his deep questions with me. I could answer only very few of them, and, in every case, only after a lot of thinking. That was a happy period for me: for the first time in my life, I intellectually was a little bit close to Medicine, which my father wanted as career for both me and my brother Demetrio. My brother indeed became a clinical physician. Thanks to Ricardo, finally I was kind of satisfying the wish of my father, by then since long passed away.

It is appropriate to say in the present occasion that all the renormalization group equations for the longest oligomers (from the pentamer to the eneamer) were calculated by hand by Ricardo. Those corresponding to the pentamer are shown in Figure 1. The whole set of calculations demanded (very many) days of patient and meticulous

\begin{tabular}{|c|c|c|c|c|c|}
\hline \multirow{2}{*}{ A. $x_{0}: C_{0}^{-}{ }^{A}$} & \multirow{2}{*}{$\begin{array}{l}\text { Growing } \\
\text { fragment }\end{array}$} & \multirow{2}{*}{ Weight } & \multicolumn{2}{|c|}{$\begin{array}{l}\text { Growth } \\
\text { efficiency }\end{array}$} & \multirow{2}{*}{ Fugacity } \\
\hline & & & \begin{tabular}{|l|l} 
\\
\end{tabular} & $\|$ & \\
\hline$\stackrel{+}{G}+$ & $\begin{array}{l}\text { Catalysing } \\
\text { fragment }\end{array}$ & $1 / 2$ & 1 & 1 & $\mathrm{~K}_{\mathrm{AT}}$ \\
\hline$\stackrel{b}{+} \vec{x}$ & & $1 / 2$ & 1 & 1 & $\mathrm{~K}_{\mathrm{AT}}$ \\
\hline 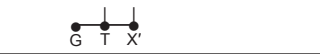 & & 1 & 1 & 1 & $\mathrm{~K}_{\mathrm{AT}} \mathrm{K}_{\mathrm{XX}}$ \\
\hline$\stackrel{b}{G} \dot{X}^{\prime}$ & & 1 & 1 & 1 & $\mathrm{~K}_{\mathrm{AT}} \mathrm{K}_{\mathrm{CG}}$ \\
\hline 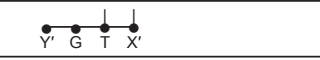 & & $1 / 2$ & 1 & 1 & $\mathrm{~K}_{\mathrm{AT}} \mathrm{K}_{\mathrm{xx^{ \prime }}}$ \\
\hline 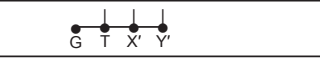 & & 1 & 1 & 1 & $\mathrm{~K}_{\mathrm{AT}} \mathrm{K}_{\mathrm{XX} \mathrm{X}^{\prime}} \mathrm{K}_{\mathrm{YY^{ \prime }}}$ \\
\hline 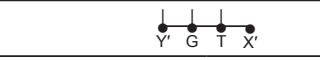 & & 1 & 1 & 1 & $\mathrm{~K}_{\mathrm{AT}} \mathrm{K}_{\mathrm{YY^{ \prime }}} \mathrm{K}_{\mathrm{GC}}$ \\
\hline$\dot{G} \stackrel{b}{T_{X^{\prime}}} \dot{Y}^{\prime}$ & & $1 / 2$ & 1 & 1 & $\mathrm{~K}_{\mathrm{AT}} \mathrm{K}_{\mathrm{CG}}$ \\
\hline 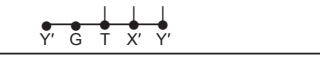 & & 1 & 1 & 1 & $\mathrm{~K}_{\mathrm{AT}} \mathrm{K}_{\mathrm{XX} \mathrm{X}^{\prime}} \mathrm{K}_{\mathrm{YY^{ \prime }}}$ \\
\hline 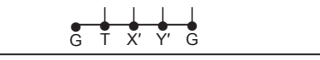 & & 1 & 1 & 1 & $\mathrm{~K}_{\mathrm{AT}} \mathrm{K}_{\mathrm{XX^{ \prime }}} \mathrm{K}_{\mathrm{YY^{ \prime }}} \mathrm{K}_{\mathrm{CG}}$ \\
\hline 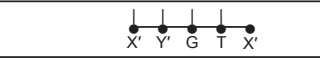 & & 1 & 1 & 1 & $\mathrm{~K}_{\mathrm{AT}} \mathrm{K}_{\mathrm{XX^{ \prime }}} \mathrm{K}_{\mathrm{YY^{ \prime }}} \mathrm{K}_{\mathrm{CG}}$ \\
\hline 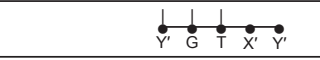 & & 1 & 1 & 1 & $\mathrm{~K}_{\mathrm{AT}} \mathrm{K}_{\mathrm{YY^{ \prime }}} \mathrm{K}_{\mathrm{CG}}$ \\
\hline 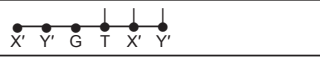 & & $1 / 2$ & 1 & 1 & $\mathrm{~K}_{\mathrm{AT}} \mathrm{K}_{\mathrm{XX^{ \prime }}} \mathrm{K}_{\mathrm{YY^{ \prime }}}$ \\
\hline 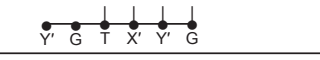 & & 1 & 1 & 1 & $\mathrm{~K}^{2}{ }_{\mathrm{AT}} \mathrm{K}_{\mathrm{XX}}, \mathrm{K}_{\mathrm{YY}^{\prime}} \mathrm{K}_{\mathrm{CG}}$ \\
\hline 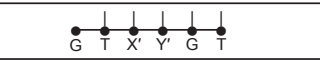 & & 1 & 1 & 1 & $\mathrm{~K}_{\mathrm{AT}}^{2} \mathrm{~K}_{\mathrm{XX}}, \mathrm{K}_{\mathrm{YY}^{\prime}} \mathrm{K}_{\mathrm{CG}}$ \\
\hline 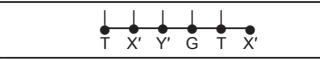 & & 1 & 1 & 1 & $\mathrm{~K}_{\mathrm{AT}}^{2} \mathrm{~K}_{\mathrm{XX}} \mathrm{K}_{\mathrm{YY^{ \prime }}} \mathrm{K}_{\mathrm{CG}}$ \\
\hline 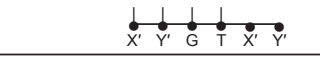 & & 1 & 1 & 1 & $\mathrm{~K}^{2}{ }_{\mathrm{AT}} \mathrm{K}_{\mathrm{XX}}, \mathrm{K}_{\mathrm{YY^{ \prime }}}, \mathrm{K}_{\mathrm{CG}}$ \\
\hline 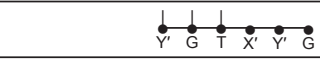 & & $1 / 2$ & 1 & 1 & $\mathrm{~K}_{\mathrm{AT}} \mathrm{K}_{\mathrm{YY^{ \prime }}} \mathrm{K}_{\mathrm{CG}}$ \\
\hline 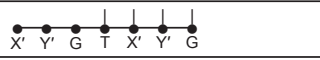 & & 1 & 1 & 1 & $\mathrm{~K}_{\mathrm{AT}} \mathrm{K}_{\mathrm{XX^{ \prime }}} \mathrm{K}_{\mathrm{YY^{ \prime }}} \mathrm{K}_{\mathrm{CG}}$ \\
\hline 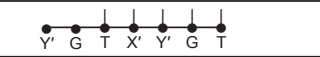 & & 1 & 1 & 1 & $\mathrm{~K}_{\mathrm{AT}} \mathrm{K}_{\mathrm{XX^{ \prime }}} \mathrm{K}_{\mathrm{YY^{ \prime }}} \mathrm{K}_{\mathrm{CG}}$ \\
\hline
\end{tabular}

\begin{tabular}{|c|c|c|c|c|}
\hline \multirow{2}{*}{ 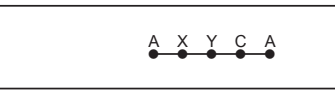 } & \multirow{2}{*}{ Weight } & \multicolumn{2}{|c|}{\begin{tabular}{|l} 
Growth \\
efficiency
\end{tabular}} & \multirow{2}{*}{ Fugacity } \\
\hline & & \begin{tabular}{|l|}
1 \\
\end{tabular} & II & \\
\hline 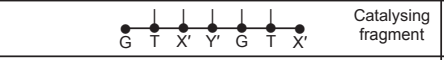 & 1 & 1 & 2 & $\mathrm{~K}_{\mathrm{AT}}^{2} \mathrm{~K}_{\mathrm{xx^{ \prime }}}, \mathrm{K}_{\mathrm{yy^{ \prime }}}, \mathrm{K}_{\mathrm{CG}}$ \\
\hline 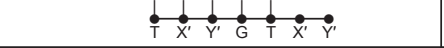 & 1 & 1 & 1 & $\mathrm{~K}_{\mathrm{AT}}^{2} \mathrm{~K}_{\mathrm{xx^{ \prime }}} \mathrm{K}_{\mathrm{yy} \mathrm{y}^{\prime}} \mathrm{K}_{\mathrm{CG}}$ \\
\hline 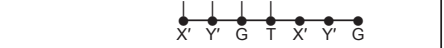 & 1 & 1 & 1 & $\mathrm{~K}_{\mathrm{AT}}^{2} \mathrm{~K}_{\mathrm{xx^{ \prime }}} \mathrm{K}_{\mathrm{yy} \mathrm{y}^{\prime}} \mathrm{K}_{\mathrm{CG}}$ \\
\hline 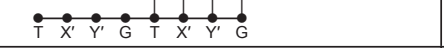 & $1 / 2$ & 1 & 1 & $\mathrm{~K}_{\mathrm{AT}}^{2} \mathrm{~K}_{\mathrm{x} x^{\prime}} \mathrm{K}_{\mathrm{yy} \mathrm{y}^{\prime}} \mathrm{K}_{\mathrm{CG}}$ \\
\hline 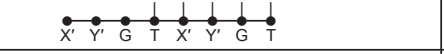 & 1 & 1 & 1 & $\mathrm{~K}_{\mathrm{AT}}^{2} \mathrm{~K}_{\mathrm{xx^{ \prime }}}, \mathrm{K}_{\mathrm{y} \mathrm{y}^{\prime}} \mathrm{K}_{\mathrm{CG}}$ \\
\hline 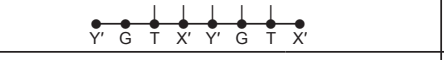 & 1 & 1 & 2 & $\mathrm{~K}_{\mathrm{AT}}^{2} \mathrm{~K}_{\mathrm{xx^{ \prime }}}, \mathrm{K}_{\mathrm{yy}}, \mathrm{K}_{\mathrm{CG}}$ \\
\hline 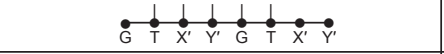 & 1 & 1 & 2 & $\mathrm{~K}_{\mathrm{AT}}^{2} \mathrm{~K}_{\mathrm{x} \mathrm{x}^{\prime}}, \mathrm{K}_{\mathrm{y} \mathrm{y}^{\prime}}, \mathrm{K}_{\mathrm{CG}}$ \\
\hline 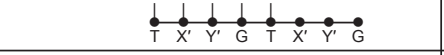 & 1 & 1 & 1 & $\mathrm{~K}^{2}{ }_{\mathrm{AT}} \mathrm{K}_{\mathrm{xx^{ \prime }}} \mathrm{K}_{\mathrm{yy^{ \prime }}} \mathrm{K}_{\mathrm{CG}}$ \\
\hline 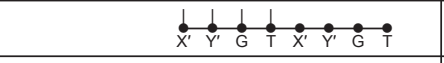 & $1 / 2$ & 1 & 1 & $\mathrm{~K}_{\mathrm{AT}}^{2} \mathrm{~K}_{\mathrm{xx^{ \prime }}}, \mathrm{K}_{\mathrm{yy^{ \prime }}} \mathrm{K}_{\mathrm{CG}}$ \\
\hline 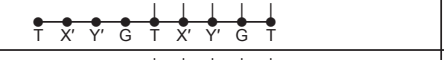 & 1 & 1 & 1 & $\mathrm{~K}_{\mathrm{AT}}^{2} \mathrm{~K}_{\mathrm{xx^{ \prime }}}, \mathrm{K}_{\mathrm{yy}}, \mathrm{K}_{\mathrm{CG}}$ \\
\hline 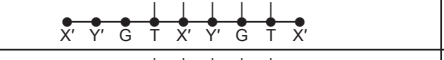 & 1 & 1 & 2 & $\mathrm{~K}_{\mathrm{AT}}^{2} \mathrm{~K}_{\mathrm{x} x^{\prime}} \mathrm{K}_{\mathrm{yy}} \mathrm{K}_{\mathrm{CG}}$ \\
\hline 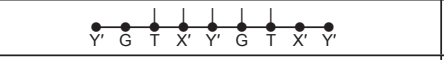 & 1 & 1 & 2 & $\mathrm{~K}_{\mathrm{AT}}^{2} \mathrm{~K}_{\mathrm{x} x^{\prime}} \mathrm{K}_{\mathrm{yy}} \mathrm{K}_{\mathrm{CG}}$ \\
\hline 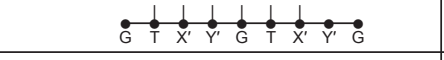 & 1 & 1 & 2 & $\mathrm{~K}_{\mathrm{AT}}^{2} \mathrm{~K}_{\mathrm{xx^{ \prime }}}, \mathrm{K}_{\mathrm{yy}}, \mathrm{K}_{\mathrm{CG}}$ \\
\hline 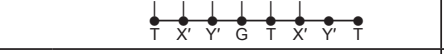 & 1 & 1 & 1 & $\mathrm{~K}_{\mathrm{AT}}^{2} \mathrm{~K}_{\mathrm{xx^{ \prime }}}, \mathrm{K}_{\mathrm{yy^{ \prime }}}, \mathrm{K}_{\mathrm{CG}}$ \\
\hline 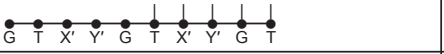 & $1 / 2$ & 1 & 1 & $\mathrm{~K}_{\mathrm{AT}}^{2} \mathrm{~K}_{\mathrm{x} \mathrm{x}^{\prime}} \mathrm{K}_{\mathrm{yy^{ \prime }}} \mathrm{K}_{\mathrm{CG}}$ \\
\hline 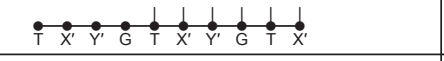 & 1 & 1 & 2 & $\mathrm{~K}_{\mathrm{AT}}^{2} \mathrm{~K}_{\mathrm{xx^{ \prime }}}, \mathrm{K}_{\mathrm{yy}}, \mathrm{K}_{\mathrm{CG}}$ \\
\hline 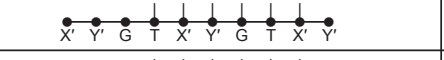 & 1 & 1 & 2 & $\mathrm{~K}_{\mathrm{AT}}^{2} \mathrm{~K}_{\mathrm{xx^{ \prime }}} \mathrm{K}_{\mathrm{yy}} \mathrm{K}_{\mathrm{CG}}$ \\
\hline 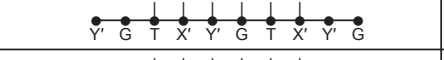 & 1 & 1 & 2 & $\mathrm{~K}_{\mathrm{AT}}^{2} \mathrm{~K}_{\mathrm{xx^{ \prime }}} \mathrm{K}_{\mathrm{yy}} \mathrm{K}_{\mathrm{CG}}$ \\
\hline 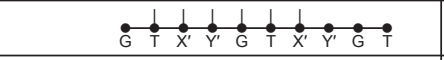 & 1 & 1 & 2 & $\mathrm{~K}_{\mathrm{AT}}^{2} \mathrm{~K}_{\mathrm{x} x^{\prime}} \mathrm{K}_{\mathrm{yy}} \mathrm{K}_{\mathrm{CG}}$ \\
\hline 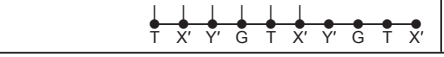 & $1 / 2$ & 1 & 1 & $\mathrm{~K}_{\mathrm{AT}}^{2} \mathrm{~K}_{\mathrm{xx^{ \prime }}}, \mathrm{K}_{\mathrm{yy}}, \mathrm{K}_{\mathrm{CG}}$ \\
\hline
\end{tabular}

Figure 1. Configurational analysis of the catalysing fragments corresponding to the growth of a pentamer. 
work by Ricardo on (very many) large computer-sheets of paper, over two meters long all together! I was teaching him renormalization group techniques. He was teaching me natural philosophy. Of the two of us, it was me who had the deepest benefit!

These early ideas about biogenesis did not end, in fact, with our three papers with Ricardo. They produced followups by Ricardo et al., ${ }^{6}$ by me et al. ${ }^{7-9}$ and by other people elsewhere (e.g. $\left.{ }^{10,11}\right)$. They attracted attention in international meetings, and even in popular media such as the Brazilian magazine VEJA. I still have in hands 68 letters/cards from scientists from all over the world asking Ricardo and myself to send them reprints of those papers. Twenty-five years ago, 68 citations were an enormous number!

Finally, let me focus on one more piece of science that emerged within the connection that Ricardo had established between Química Nova and myself. The chemistry Brazilian journal had decided to dedicate a special issue to the 150th Anniversary of Boltzmann birth, and I was one of the contributors. I was at the time in East Lansing, at Michigan State University, spending a long sabbatical. At that time I realized that virtually all the main equations of nonextensive statistical mechanics - a generalization of BoltzmannGibbs (BG) statistical mechanics that I proposed in $1988^{12}$ - could be elegantly rewritten in the same forms as those of the BG theory, by just generalizing the mathematical form of the usual logarithmic and exponential functions. These generalizations are the following ones:

$\ln _{q} x \equiv \frac{x^{1-q}-1}{1-q}\left(q \in \Re ; x>0 ; \ln _{1} x=\ln x\right)$

and its inverse

$e_{q}^{x}=[1+(1-q) x]^{1 /(1-q)}\left(q \in \Re ; e_{1}^{x}=e^{x}\right)$

if $1+(1-q) x \geq 0$, and zero otherwise. Both generalizations were introduced for the first time ${ }^{13}$ in that Química Nova special issue, and are widely used nowadays in the literature of the nonextensive theory. Thanks, Ricardo!

\section{Acknowledgements}

With my very best and warmest wishes for your birthday, Ricardo! "Na ta ekatostissis." 14

\section{References}

1. Translated from Portuguese: "You did not aggress, you gave it back. Because in the inland of the North East [Ricardo's birthplace], and in the dry valleys of Greece [my birthplace], we do not carry an offense to our home."

2. Tsallis, C.; Ferreira, R. On the origin of self-replicating information-containing polymers from oligomeric mixtures. Phys. Lett. A 1990, 99, 461.

3. Ferreira, R; Tsallis, C. On the role of complementarity in biogenesis: A critical phenomenon approach. J. Theor. Biol. $1985117,303$.

4. Tsallis, C.; Ferreira, R. A critical phenomenon approach of biogenesis, in Statistical Physics, ed. H.E. Stanley, Physica A 140, 336-348 (1986).

5. Anderson, P. W. Suggested model for prebiotic evolution: The use of chaos. Proc. Nat. Acad. Sci. U.S.A. 1983 80, 3386.

6. Ferreira, R.; Coutinho, K. R. Simulation studies of selfreplicating oligoribotides with a proposal for the transition to a peptide-assisted stage. J. Theor. Biol. 1993 164, 291.

7. Tsallis, C. Biogenesis: Diversity, selection and fractality. Quím. Nova 1988, 11, 127.

8. Herrmann, H. J.; Tsallis, C. Biogenesis and the growth of DNAlike polymer chains: A computer simulation. Physica A 1988, 153, 202.

9. da Silva, L.; Mundim, K. C.; Tsallis, C. Effect of cross-links on the autocatalytic polymerization of RNA-like chains. Physica A 1998, 259, 415.

10. Amitrano, C.; Peliti, L.; Saber, M. Population dynamics in a spin-glass model of chemical evolution. J. Mol. Evol. 1989, 29, 513.

11. Kelly, K.; Jan, N. Modeling the onset of life. Physica A $\mathbf{1 9 9 0 ,}$ $170,52$.

12. Tsallis, C. Possible generalization of Boltzmann-Gibbs statistics. J. Stat. Phys. 1988, 52, 479.

13. Tsallis, C. What are the numbers that experiments provide?, Quím. Nova 1994, 17, 468.

14. Translated from Greek: "I wish you to complete one hundred years." 